\title{
The pregnancy hormones human chorionic gonadotropin and progesterone induce human embryonic stem cell proliferation and differentiation into neuroectodermal rosettes
}

Miguel J Gallego ${ }^{1 \dagger}$, Prashob Porayette ${ }^{1 \dagger}$, Maria M Kaltcheva ${ }^{1}$, Richard L Bowen ${ }^{2}$, Sivan Vadakkadath Meethal ${ }^{1,5}$, Craig S Atwood ${ }^{1,3,4^{*}}$

\begin{abstract}
Introduction: The physiological signals that direct the division and differentiation of the zygote to form a blastocyst, and subsequent embryonic stem cell division and differentiation during early embryogenesis, are unknown. Although a number of growth factors, including the pregnancy-associated hormone human chorionic gonadotropin (hCG) are secreted by trophoblasts that lie adjacent to the embryoblast in the blastocyst, it is not known whether these growth factors directly signal human embryonic stem cells (hESCs).

Methods: Here we used hESCs as a model of inner cell mass differentiation to examine the hormonal requirements for the formation of embryoid bodies (EB's; akin to blastulation) and neuroectodermal rosettes (akin to neurulation).

Results: We found that hCG promotes the division of hESCs and their differentiation into EB's and neuroectodermal rosettes. Inhibition of luteinizing hormone/chorionic gonadotropin receptor (LHCGR) signaling suppresses hESC proliferation, an effect that is reversed by treatment with hCG. hCG treatment rapidly upregulates steroidogenic acute regulatory protein (StAR)-mediated cholesterol transport and the synthesis of progesterone $\left(\mathrm{P}_{4}\right)$. hESCs express $\mathrm{P}_{4}$ receptor $\mathrm{A}$, and treatment of hESC colonies with $\mathrm{P}_{4}$ induces neurulation, as demonstrated by the expression of nestin and the formation of columnar neuroectodermal cells that organize into neural tubelike rosettes. Suppression of $\mathrm{P}_{4}$ signaling by withdrawing $\mathrm{P}_{4}$ or treating with the $\mathrm{P}_{4}$-receptor antagonist RU-486 inhibits the differentiation of hESC colonies into EB's and rosettes.

Conclusions: Our findings indicate that hCG signaling via LHCGR on hESC promotes proliferation and differentiation during blastulation and neurulation. These findings suggest that trophoblastic hCG secretion and signaling to the adjacent embryoblast could be the commencement of trophic support by placental tissues in the growth and development of the human embryo.
\end{abstract}

\section{Introduction}

Zygotic division into a blastocyst establishes the extraembryonic tissues (trophoblast layer or outer cell mass) that support the embryonic embryoblast (inner cell mass) early in embryogenesis. Trophoblasts secrete an

\footnotetext{
* Correspondence: csa@medicine.wisc.edu

+ Contributed equally

'Geriatric Research, Education and Clinical Center, Veterans Administration Hospital and Department of Medicine, University of Wisconsin-Madison School of Medicine and Public Health, 2500 Highland Avenue, Madison, WI 53705, USA

Full list of author information is available at the end of the article
}

array of hormones [1-4], including hCG, during the migration of the blastocyst through the fallopian tube and its implantation into the endometrium. The dramatic elevation in the production of hCG by trophoblasts at this early embryonic stage (from 5 to $\geq 1,000$ $\mathrm{mIU} / \mathrm{ml}$ in the maternal serum) [2,5] signals both the corpus luteum and trophoblast [3] to synthesize and secrete $\mathrm{P}_{4}$ [6]. This is required for the maintenance of the endometrium, blastocyst attachment, and syncytiotrophoblast invasion into the endometrium [7]. 
However, the role of hCG in early human embryogenesis is unknown.

Given the close spatial localization of the developing trophoblast layer to the embryoblast, it is conceivable that trophoblast-associated hormones directly signal the growth and development of the embryoblast. hCG, and luteinizing hormone (LH), which shares $83 \%$ amino acid sequence homology, bind a common receptor, the LH/ human chorionic gonadotropin receptor (LHCGR) with similar affinity [8]. LHCGR has been identified on all tissues studied to date (reviewed in $[9,10]$ ), although it has not been reported on hESCs.

Recent evidence from our laboratory supports trophoblastic hCG and $\mathrm{P}_{4}$ signaling to embryoblast-derived hESCs and includes (a) hCG markedly increases hESC expression of the adhesion and neuritogenic protein amyloid- $\beta$ precursor protein (A $\beta P P)[11]$, (b) $\mathrm{P}_{4}$ is required for nonamyloidogenic processing of $A \beta P P$ during hESC differentiation [11], and (c) $\mathrm{P}_{4}$ signaling is necessary for human embryoid body (EB) differentiation [4]. Moreover, it is known that (hyperglycosylated) hCG $\beta$ has potent cell growth and invasion properties and acts as an autocrine factor on extravillous invasive cytotrophoblast cells to initiate and control invasion during implantation and the establishment of hemochorial placentation [12]. hCG also promotes these processes during malignancy in invasive hydatidiform mole, choriocarcinoma, and testicular cancers [12].

In this study we tested whether the trophoblastic hormones hCG and $\mathrm{P}_{4}$ signal hESC proliferation and differentiation. By using this in vitro model of early human embryogenesis, we found that hCG/LH signal via LHCGR to promote hESC proliferation and steroidogenesis ( $\mathrm{P}_{4}$ synthesis), and that $\mathrm{P}_{4}$ signaling is obligatory for both $\mathrm{EB}$ and neuroectodermal rosette differentiation.

\section{Materials and methods}

\section{Human embryonic stem cell culture}

\section{Propagation of human embryonic stem cells}

Pluripotent H9 hESCs (passage 22 to 32; XX karyotype; also known as WA09, a National Institutes of Health registered line) were obtained from the WiCell Research Institute (Madison, WI). The research was approved by the UW-Madison Department of Medicine. Cells were plated onto irradiated mouse embryonic fibroblast (MEF) cells $\left(1.875 \times 10^{5}\right.$ cells per well; Biovintage, San Diego, CA) in six-well plates (Fisher Scientific, Pittsburgh, PA) coated with $1 \mathrm{ml}$ of sterile $0.1 \%$ gelatin (Sigma-Aldrich Co., St. Louis, MO) solution. Before the addition of hESCs, MEF cells were grown in Dulbecco's Modified Eagle Media (DMEM) (Invitrogen, Carlsbad, CA) supplemented with $10 \%$ heat-inactivated fetal bovine serum (FBS; Invitrogen) and $1 \%$ nonessential amino acids (NEAAs; Invitrogen). After 24 hours of
MEF plating, hESCs were plated on this MEF feeder layer and grown in the presence of DMEM-F12 media (Invitrogen) supplemented with $1 \%$ NEAA, $1 \mathrm{mM}$ L-glutamine (Invitrogen), $0.1 \mathrm{~m} M$ 2-mercaptoethanol (Sigma-Aldrich Co.), $4 \mathrm{ng} / \mathrm{ml} \mathrm{bFGF} \mathrm{(Invitrogen),} \mathrm{and}$ 20\% Knockout Serum Replacement (KOSR; Invitrogen). Continual propagation of cells required colonies to be enzymatically lifted with $1 \mathrm{ml}$ of a sterile solution of collagenase type IV (Invitrogen) (1 mg/ml of DMEM-F12), dissected into multiple small pieces, and transferred onto a fresh MEF feeder layer every 4 to 5 days. hESCs also were grown on Matrigel (BD Biosciences, San Jose, CA), a basement-membrane preparation extracted from a murine Englebreth-Holm-Swarm sarcoma, in the presence of mTeSR1 medium (StemCell Technologies, Inc., Vancouver, British Columbia, Canada), a defined culture medium developed by WiCell Research Institute [13]. Matrigel $(100 \mu \mathrm{g} / \mathrm{ml}$ in DMEM-F12; $1 \mathrm{ml})$ was added to each well of a six-well plate and left for 1 hour at room temperature or at $4^{\circ} \mathrm{C}$ overnight. hESCs were transferred onto these plates, and cells were passaged by enzymatic lifting with a sterile solution of neutral protease (Dispase; $1 \mathrm{mg} / \mathrm{ml}$ in DMEM-F12; Invitrogen), the colonies dissected into multiple small pieces and transferred onto new plates coated with Matrigel, and cultured in mTeSR1 medium. The culture medium $(2.5 \mathrm{ml}$ per well) was replaced every day in all these culture conditions.

\section{Differentiation of hESCs into embryoid bodies}

This protocol mimics the formation of the blastocyst during human embryogenesis [14]. Pluripotent hESCs (H9) grown on MEF in a six-well plate were rinsed twice with $1 \mathrm{ml}$ of Dulbecco's Phosphate-Buffered Saline (DPBS, without calcium or magnesium; Invitrogen) per well. Colonies were then incubated with $1 \mathrm{ml}$ of Dispase $\left(0.5 \mathrm{mg} / \mathrm{ml}\right.$ in DMEM-F12) at $37^{\circ} \mathrm{C}, 5 \% \mathrm{CO}_{2}$, until the colonies detached intact while avoiding dispersing the colonies into single cells. T25 flasks (Fisher Scientific) were incubated with $5 \mathrm{ml}$ of a $2 \%$ poly (2-hydroxyethyl methacrylate) (Poly-HEMA; Sigma-Aldrich Co.) solution for 5 minutes. The flask was placed in a horizontal position for 5 minutes with the cap on. This allowed optimal coating of the working-surface area of the flask. This process was repeated for each side of the flask. The caps of coated flasks were opened, and the Poly-HEMA solution was sucked off. The open flasks were allowed to remain in the hood for 1 hour to dry. After 1 hour, the surface was washed twice with DPBS, and the detached hESC colonies were cultured in $15 \%$ Characterized FBS (Invitrogen) and 85\% Iscove's Modified Dulbecco's Medium (IMDM; Invitrogen) in these PolyHEMA-coated T25 flasks and incubated under standard conditions $\left(37^{\circ} \mathrm{C}, 5 \% \mathrm{CO}_{2}\right)$ on an orbital shaker (Boekel Orbitron, Feasterville, PA) with constant gentle rocking for 10 to 14 days to allow the hESCs to aggregate into 
cystic spheroidal structures. The Poly-HEMA coat and the constant gentle rocking prevented the adherence of these spheroidal structures to the flask.

\section{Differentiation of hESCs into neural precursor cells}

The protocol described later for the differentiation of hESCs into columnar neural precursor cells (NPCs) mimics in vivo NPC development in terms of timing and morphology [15]. In vitro, hESCs differentiate into columnar NPCs that organize into neural tube-like rosettes within 12 to 14 days. Considering that hESCs are equivalent to a 5 to 6 day embryo, development of the NPCs in vitro takes about 18 to 20 days, the time window when the neural tube forms in a human embryo $[16,17]$.

Pluripotent hESC (H9) colonies grown on MEF in sixwell plates were rinsed twice with DPBS ( $1 \mathrm{ml}$ per well) and then treated with Dispase $(1 \mathrm{ml}$ of $1 \mathrm{mg} / \mathrm{ml}$ in DMEM-F12) and incubated at $37^{\circ} \mathrm{C}, 5 \% \mathrm{CO}_{2}$ until the edges of the colonies began to curl up. The plate was then swirled to detach the colonies intact but without dispersing the colonies into individual cells. The hESC colonies were grown in T25 flasks in a special ES cellgrowth medium (78.5\% DMEM-F12, 20\% KOSR, 1\% NEAA, $1 \mathrm{~m} M$ L-glutamine, $0.1 \mathrm{~m} M$ 2-mercaptoethanol) for 4 days with daily replacement of media to form ESC aggregates. ESC aggregates were then adhered to the culture surface, where they formed monolayer colonies in a chemically defined neural induction medium $(32.6 \%$ F-12 (Invitrogen), 65.2\% DMEM, 1\% N2 supplement (Invitrogen), $1 \%$ NEAA, $0.2 \%$ of $1 \mathrm{mg} / \mathrm{ml} \mathrm{Heparin}$ (Sigma-Aldrich Co.), and $10 \mathrm{ng} / \mathrm{ml} \mathrm{bFGF).} \mathrm{Under} \mathrm{this}$ culture condition, columnar NPCs appear in the center of each colony and organize into neural tube-like rosettes after a total of 9 to 10 days of differentiation culture. The neural induction medium was replaced every other day. The NPCs in the rosettes were selectively isolated through differential enzymatic treatment by using Dispase $(0.5 \mathrm{mg} / \mathrm{ml}$ in DMEM-F12) and incubated for 2 hours in neural induction medium to allow the nonneural cells to attach differentially attach to the T25 flasks. After this, the floating cells (mostly aggregates of NPCs) were transferred to new T25 flasks where they rolled up to form round clusters. Some of these clusters were collected and probed for nestin to confirm NPC differentiation. The remaining formed clusters were continuously passaged by manually splitting the clusters by using a sterile scalpel.

\section{Treatment of hESCs}

Pluripotent H9 hESCs were plated in six-well plates coated with Matrigel in $2.5 \mathrm{ml}$ of mTeSR1 medium per well. After overnight culture, cells were treated every day in different experiments with (a) hCG (0 to 50,000 $\mathrm{mIU} / \mathrm{ml}$; Ray Biotech Inc., Norcross, GA) in mTeSR1 medium for 6 days; (b) LH (0 to $100 \mathrm{mIU} / \mathrm{ml}$; National
Peptide Hormone Program, Harbor-UCLA, Los Angeles, CA); (c) $\mathrm{P}_{4}(2 \mu M), \mathrm{E}_{2}(10 \mathrm{n} M), \mathrm{RU}-486(20 \mu M$; stock RU-486 was solubilized in EtOH and then diluted into media; Sigma Laboratories, St. Louis, MO), DMSO (equivalent volume to that added to sex steroids) and $\mathrm{EtOH}$ (equivalent volume to that added to RU-486) for 5 to 10 days in TESR 1 medium (lacking Li); (d) affinity purified anti-LHCGR rabbit polyclonal antibody $(1: 1,000,1: 200,1: 100$ dilution) in combination with hCG; or (e) lipofectamine (control), lipofectamine + LHCGR sense oligonucleotides or lipofectamine + LHCGR P-antisense oligonucleotides for 6 days. For experiments using oligomers with phosphorothioate bonds (antisense-P; Integrated DNA Technology, Coralville, IA), oligomers were added to media $(240 \mu \mathrm{l})$ that had been preincubated with lipofectamine $(4 \mathrm{ng} / \mu \mathrm{l}$; Invitrogen) for 5 minutes at room temperature. This mixture was then incubated at room temperature for 20 minutes before the addition to cells. Antisense-P was used at a final concentration of $0.4 \mu M$.

Cells were counted by using the trypan blue staining method and collected in Dulbecco's phosphate-buffered saline (DPBS) and stored at $-80^{\circ} \mathrm{C}$ before analysis of mRNA or protein expression or both. Media from hCGtreated cells were pooled each day for 6 days $(15 \mathrm{ml}$ total), lyophilized, and resuspended in $2 \mathrm{ml}$ of TESR 1 medium for EIA of $\mathrm{P}_{4}$ (Cayman Chemical Company, Ann Arbor, MI).

\section{Progesterone receptor antagonist treatment of hESC colonies \\ EB formation}

ESCs were allowed to form colonies by culturing for 4 days on an MEF feeder layer, as described earlier, and then were enzymatically lifted and the colonies placed into EB medium (containing serum) in the absence (control) or presence of RU-486 $(20 \mu M)$ and rocked gently for an additional 10 days to allow EB formation. Structures were then assessed morphologically.

\section{Rosette formation}

hESCs were allowed to form colonies by culturing for 4 days on an MEF feeder layer. Colonies were then enzymatically lifted and placed into EB medium (containing serum) and rocked gently for an additional 4 days. Colonies were then placed in neural induction media without $\mathrm{P}_{4}$ (using an especially made medium containing all ingredients except $\left.\mathrm{P}_{4}\right)$, with $\mathrm{P}_{4}(2 \mu M)$, and/or RU-486 $(20 \mu M)$ for an additional 11 days. At 19 days, the structures were assessed morphologically and then collected for immunoblot analyses.

\section{mRNA Expression}

Total RNA was isolated from cultured hES cells by using the RNeasy Mini Kit (Qiagen, Valencia CA) 
according to the manufacturer's instructions. LHCGR, LH $\beta$, hCG, and steroid acute regulatory protein (StAR) cDNA were synthesized and amplified by using the SuperScript III One-Step RT-PCR system (Invitrogen). Both cDNA synthesis and PCR amplification were carried out by using gene-specific primers (IntegratedDNA-Technologies, Coralville, IA): LHCGR forward 5' CCCTCACCGTCATCACTCTAG 3', reverse 5' CGATT TCACCTGCATGGC $3^{\prime}, L H \beta$ forward 5' GCTACTGC CCCACCATGATG $3^{\prime}$, reverse 5' ATGGACTCGAAG CGCACATC $3^{\prime}$, Isoform V of $h C G \beta$ forward $5^{\prime}$ ATCA CCGTCAACACCACCATCTGT 3', reverse 5' AAGCCT TTATTGTGGGAGGATCGG, StARD1 forward 5' CGG CAGCGACCCCACCACT 3', reverse 5'AGCCGGAACACCTTGCCCACAT 3'. PCR amplification of LHCGR was performed for 35 cycles of $95^{\circ} \mathrm{C}$ for 30 seconds, $62^{\circ} \mathrm{C}$ for 45 seconds, $72^{\circ} \mathrm{C}$ for 60 seconds, and final extension time of 5 minutes. PCR amplification of StAR was performed for 35 cycles of $95^{\circ} \mathrm{C}$ for 30 seconds, $64^{\circ} \mathrm{C}$ for 45 seconds, $72^{\circ} \mathrm{C}$ for 60 seconds, and a final extension time of 5 minutes. PCR amplification of $L H \beta$ was performed for 35 cycles of $95^{\circ} \mathrm{C}$ for 30 seconds, $63^{\circ}$ $\mathrm{C}$ for 45 seconds, $72^{\circ} \mathrm{C}$ for 60 seconds, and final extension time of 5 minutes. PCR amplification of $h C G$ was performed for 35 cycles of $95^{\circ} \mathrm{C}$ for 30 seconds, $63^{\circ} \mathrm{C}$ for 45 seconds, $72^{\circ} \mathrm{C}$ for 60 seconds, and final extension time of 5 minutes. The PCR product was stained with Gel Star Nucleic Acid Stain (Cambrex Bio Science, Rockland, ME), run on 2.5\% Metaphor agarose gel (Cambrex Bio Science), and imaged by using $\mathrm{EC}^{3}$ Imaging System (UVP Bioimaging System, Upland, CA).

\section{Immunoblotting}

Cells were collected and immunoblot analyses performed as previously described $[11,18]$. Because of the dramatic changes that occur in protein expression during the dynamic developmental period under consideration, it was difficult to find an internal control to demonstrate equal protein loading (see $[11,18]$ ). Given this variability, we chose to load samples according to total protein, as previously described [19]. The following antibodies were used throughout this study: Anti-human nestin monoclonal antibody (Chemicon International, Temecula, CA); affinity purified anti-human LH/hCG receptor polyclonal antibody generated against the N-terminal 15-38 amino acids (New England Peptides, Atlanta, GA); anti-human Oct3/4 monoclonal antibody, anti-human PR rabbit polyclonal antibody (C-19) generated against the $\mathrm{C}$-terminus, glyceraldehyde-3-phosphate dehydrogenase (GAPDH) goat polyclonal antibody $(\mathrm{V}-18)$, anti-human $\beta$-actin goat polyclonal antibody (C-11), horseradish peroxidase-linked goat anti-mouse, goat anti-rabbit, and donkey anti-goat IgG (Santa Cruz Biotechnology); anti-human LH $\beta$ polyclonal antibody
(National Hormone and Peptide Program, HarborUCLA Medical Center, Torrance, CA) [20]; anti-human StAR polyclonal antibody (a kind gift of Dr. Strauss, University of Pennsylvania [21]).

\section{Enzyme immunoassay}

hESCs were treated with hCG $(500 \mathrm{mIU} / \mathrm{ml})$ in TESR1 media each day for 6 days, the media collected and pooled each day ( $15 \mathrm{ml}$ total), lyophilized and resuspended in $2 \mathrm{ml}$ of TESR 1 media for enzyme immunoassay (EIA) of $\mathrm{P}_{4}$ (Cayman Chemical Company) according to the manufacturer's instructions.

\section{Statistical analysis}

Statistical analysis was performed by using the Student's $t$ test and ANOVA analyses followed by pair-wise comparisons with Fisher's protected least significant difference procedure (PLSD) to determine significant changes between treatment groups (Statview 5.0 \& SuperAnova 3.0 programs; SAS Institute, Inc.).

\section{Results}

To examine the functionality of trophoblastic hCG signaling to the embryoblast, we first examined whether the LHCGR was expressed by pluripotent hESCs. Fulllength mature LHCGR (92 kDa) [2] was detected in hESCs, and expression was not altered on differentiation into EB's, which recapitulate the early stages of perimplantation embryos [22], or into neuroectodermal rosettes, which consist of $>90 \%$ columnar NPCs and are the in vitro equivalent of a rudimentary neural tube [15] (Figure 1a, upper panel). Decreased Oct-3/4 expression (Figure 1a, middle panel) together with bright-field analysis (not shown) indicated lineage commitment and loss of pluripotency during the differentiation of hESC colonies into rosettes. RT-PCR of RNA extracted from pluripotent hESCs confirmed the presence of LHCGR message (Supplemental figure S1 in Additional file 1). The comparable level of LHCGR expression between the different cell lineages is suggestive of a basal requirement for LH/hCG signaling during these early stages of embryogenesis.

Because hCG is mitogenic toward epithelial and endothelial cells of the endometrium and is a marker of carcinogenesis [23], we tested whether hCG was generated by hESCs and is mitogenic toward hESCs. RT-PCR amplification of RNA extracted from pluripotent hESCs by using sequence-specific primers confirmed the presence of both hCG $\beta$ isoform V and LH $\beta$ message (data not shown). Although full-length mature $30-\mathrm{kDa} \mathrm{LH}$ protein ( $\alpha$-GSU + LH $\beta$ subunits) and other variants of LH (47 kDa and $60 \mathrm{kDa}$ ) [20] could be detected with immunoblot analysis (Figure 1b), hCG was not detectable by immunoblot, as previously reported for hESCs 
(a)

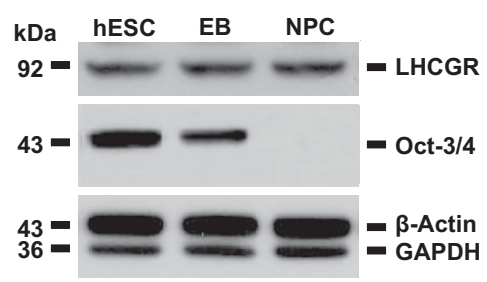

(b)

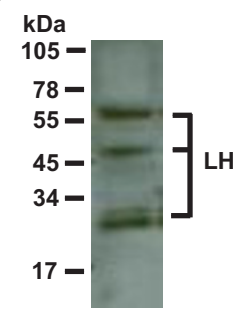

(d)

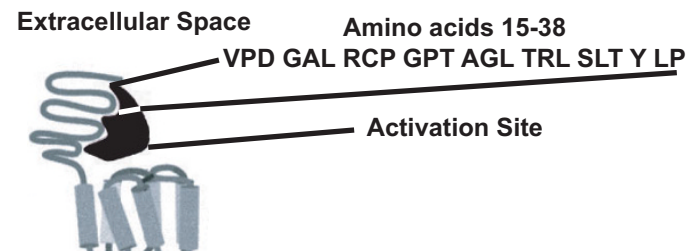

A. $500 \mathrm{mlU} / \mathrm{mL}$ hCG

Intracellular Space

B. 1:1000 LHCGR antibody

C. 1:200 LHCGR antibody

D. 1:100 LHCGR antibody

(e)

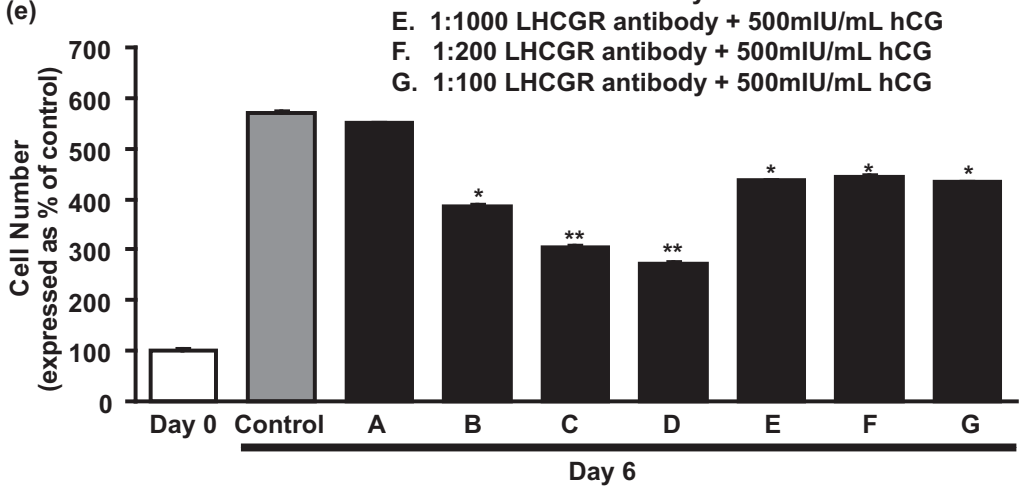

(c)

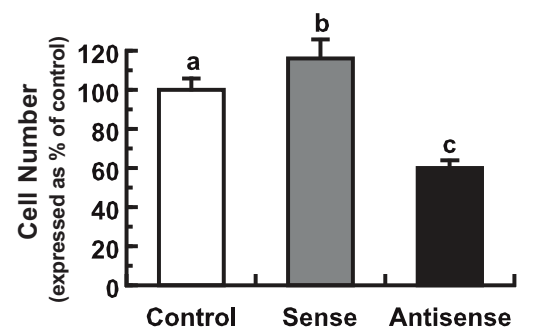

(f)

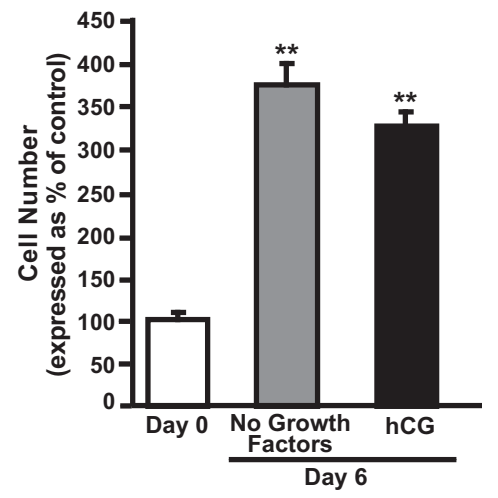

Figure 1 hCG signals hESC proliferation via LHCGR. (a) Pluripotent H9 hESC, EBs and NPC lysates were analyzed by immunoblot with (i) an affinity-purified anti-human LH/hCG receptor polyclonal antibody against the N-terminal 15-38 amino acids; (ii) a monoclonal antibody against Oct-3/4 (C-10; against 1-134 amino acids of human Oct-4), and (iii) monoclonal antibodies against human $\beta$-actin and GAPDH [11,18]. Molecularweight markers are shown on the left of immunoblots. (b) Protein from cell lysates of hESCs were analyzed with immunoblot by using a polyclonal antibody against LHß [20]. (c) hESCs were treated with lipofectamine (control), lipofectamine + LHCGR sense oligonucleotides, or lipofectamine + LHCGR antisense-P oligonucleotides for 6 days, and the cells were then counted by using the trypan blue method. Results are expressed as mean \pm SEM, $n=4$; significant differences between groups is indicated by different letters, $P<0.05$. (d) Schematic of the LHCGR activation site and binding site of rabbit polyclonal antibody against amino acids 15 to 38 of the extracellular binding domain of LHCGR. (e) hESCs grown in six-well plates coated with Matrigel in mTeSR1 media were treated for 6 days with (i) hCG (500 mlU/ml; lane A); (ii) increasing concentrations of the affinity-purified rabbit polyclonal antibody against amino acids 15 to 38 of the extracellular binding domain of LH/hCG receptor (1:1,000, 1:200, 1:100; lanes B, C, and D, respectively); and (iii) in combination with (500 mlU/ml of hCG (lanes E, F, and G). Cell number was counted by using the trypan blue assay. Results are expressed as mean $\pm \mathrm{SEM}, n=3 ;{ }^{*} P<0.05 ;{ }^{*} P<0.005$ compared with day 6 control. (f) hESCs were cultured in growth factor-free TESR1 medium \pm hCG $(500 \mathrm{mlU} / \mathrm{ml})$ for 6 days, and cell number was measured by using the trypan blue assay. Results are expressed as mean $\pm \mathrm{SEM}, n=3{ }^{* *} P<0.005$ compared with 6 day control.

[3], suggesting differential translational control of the expression of these gonadotropins early in embryogenesis. These results suggest that before hESC differentiation into trophoblasts, which are known to secrete hCG [3], LH expressed by hESCs may act in an autocrine manner on hESCs. To examine the requirement for LH/ hCG signaling in the proliferation of hESCs in vitro, we treated hESCs with P-antisense oligonucleotides against
LHCGR. P-antisense oligonucleotides significantly decreased hESC proliferation (48\%) compared with sense oligonucleotide-treated hESCs (Figure 1c). To confirm that hESC production of LH or trophoblastic production of hCG promotes hESC proliferation, we treated hESCs with increasing concentrations of an antibody against amino acids 15 to 38 of the extracellular activation site of LHCGR (Figure 1d) [24]. This antibody 
significantly reduced hESC proliferation in a dosedependent fashion compared with 6-day untreated controls (Figure 1e; 48\% reduction with 1:100 diluted antibody). Addition of hCG to hESCs treated with this blocking antibody reversed this effect, confirming the specificity of the antibody for the receptor and of hCG signaling for hESC proliferation. Similar results were obtained with LH treatment (data not shown). Treatment of hESC with a physiologically relevant concentration of hCG $(500 \mathrm{mIU} / \mathrm{ml})$ in growth factor-free TESR1 culture medium resulted in a 3.3-fold increase in cell proliferation after 6 days (Figure 1f). Surprisingly, a similar increase (3.7-fold) in hESC proliferation was observed in growth factor-free TESR1 culture media (that is, TESR1 media containing no bFGF and TGF- $\beta$ ), suggesting the autocrine production of hCG/LH (or other mitogenic factors) by hESCs or hESCs that had differentiated into trophoblasts in our cultures, as previously reported by Thomson et al. [25]. The high binding affinities $\left(K_{\mathrm{d}} \approx 0.4-5.5 \times 10^{-10} \mathrm{M}\right)$ of hCG/LH for the human receptor $[26,27]$ indicates that the autocrine production of even very low concentrations of these gonadotropins by hESCs (or trophoblasts, as reported by Golos et al., [3]) is sufficient to signal hESC proliferation. A low level of hCG/LH expression by hESC/trophoblasts also is consistent with the high binding capacity $(\sim 2.2 \mathrm{fmol} / \mathrm{mg}$ tissue) of hCG for LHCGR [26]. In this respect, knockdown of Oct4 expression in hESC induces hCG and Gcm1 expression [28] and indicates that any small differentiation of hESC in our cultures may provide sufficient hCG for hESC proliferation. Together, these results suggest the presence of an hCG/ LH-dependent mechanism that signals embryonic growth.

hCG functions to increase trophoblast and corpus luteal $\mathrm{P}_{4}$ production $[6,29]$. To examine whether hCG induces steroidogenesis in hESCs, as in steroidogenic tissues, we examined the expression of StAR, a key ratelimiting step in the production of steroids [30]. hESCs were found to express StAR mRNA and protein $(37-\mathrm{kDa}$, $30-\mathrm{kDa}$, and $20-\mathrm{kDa}$ variants; Figure $2 \mathrm{a}$ ). Increases were found in the expression of the mature variant $(37 \mathrm{kDa})$ and decreases in the expression of the truncated (30- and $20-k D a)$ variants of StAR with differentiation of hESCs into EBs and rosettes (Figure 2a). Because truncation of the $37-\mathrm{kDa}$ to the $30 / 32-\mathrm{kDa}$ variants of StAR is indicative of increased cholesterol transport across the mitochondrial membrane for steroidogenesis [30], these results suggest a decreased requirement for steroidogenesis in more-differentiated cell lineages.

To assess the steroidogenic potential of hESCs, we treated hESCs with hCG and measured $\mathrm{P}_{4}$ secretion into the media. hCG $(500 \mathrm{mIU} / \mathrm{ml})$ treatment increased $\mathrm{P}_{4}$

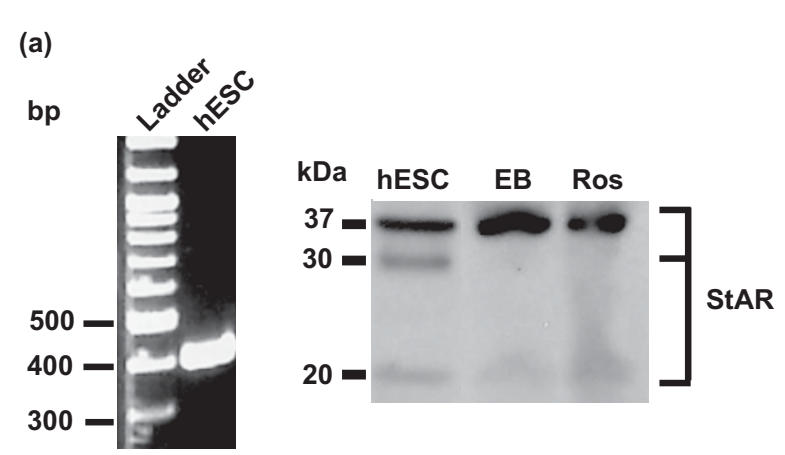

(b)

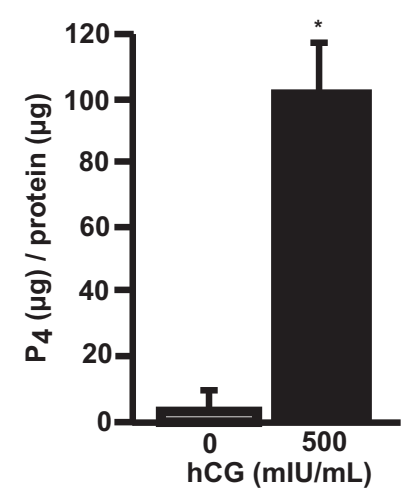

Figure 2 hCG induces the synthesis and secretion of $P_{4}$ by hESCs. (a) Total RNA isolated from hESCs was amplified by RT-PCR by using two pairs of sequence-specific primers for StAR. The expected 404-bp and 408-bp cDNA fragments were detected (left panel). Equal amounts of protein from cell lysates of hESCs, EBs and rosettes were analyzed with immunoblot with an anti-human StAR polyclonal antibody [21] (right). Molecular-weight markers are shown on the left. (b) The concentration of $\mathrm{P}_{4}$ secreted into the media from hESCs treated \pm hCG $(500 \mathrm{mlU} / \mathrm{ml})$ for 6 days. Results are expressed as micrograms $\mathrm{P}_{4}$ per microgram cellular protein, mean $\pm \mathrm{SEM}, n=3 ;{ }^{*} P<0.001$.

secretion into the media 15 -fold (Figure $2 \mathrm{~b}$ ), suggesting that $\mathrm{P}_{4}$ may signal hESCs.

Analysis of hESCs and EBs indicated that these cells express $\mathrm{P}_{4}$ receptor A (PR-A) (Figure 3a), as was previously reported for the mRNA [31] and murine ESCs [32], suggesting that $\mathrm{P}_{4}$ could signal hESC differentiation. PR-A expression did not change in hESCs after treatment with $\mathrm{P}_{4}$ or the PR antagonist RU-486 (Figure 3a). That PR-A is functional in hESCs is supported by the finding that $\mathrm{P}_{4}$ treatment decreases truncation of the $37-\mathrm{kDa}$ StAR variant (increasing the 37- to $30-\mathrm{kDa}$ ratio by $83 \%$; Figure $3 \mathrm{~b}$ ). These results also indicate that mechanisms at the level of both StAR expression and processing exist to regulate hESC steroidogenesis. Together, these results indicate that negative-feedback pathways exist for the regulation of hCG/LH signaling 

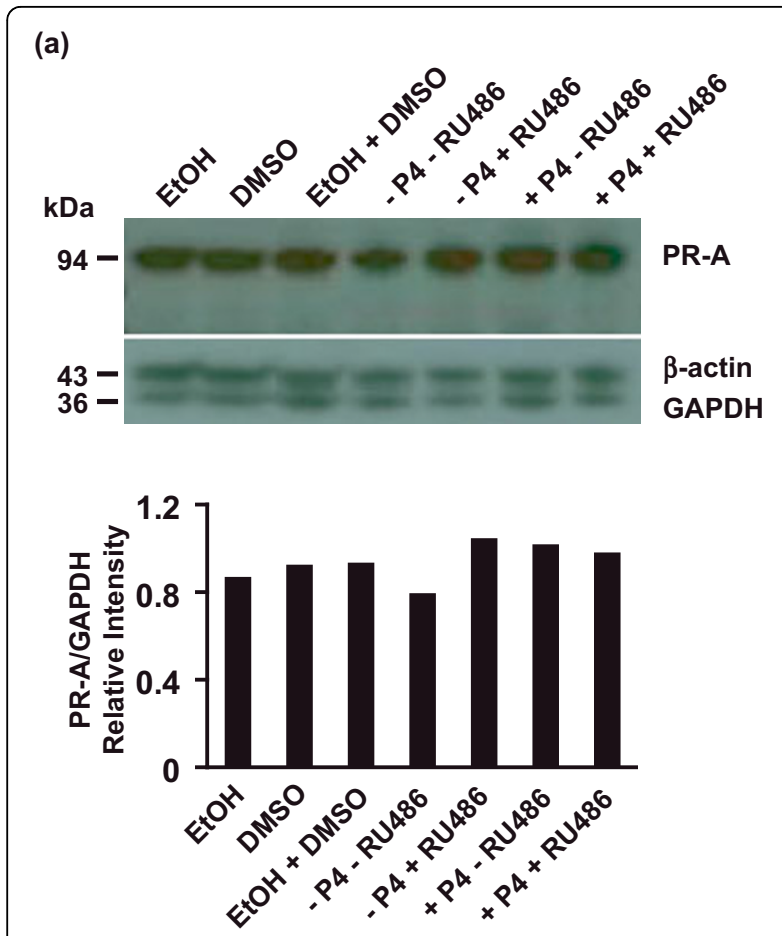

(b)

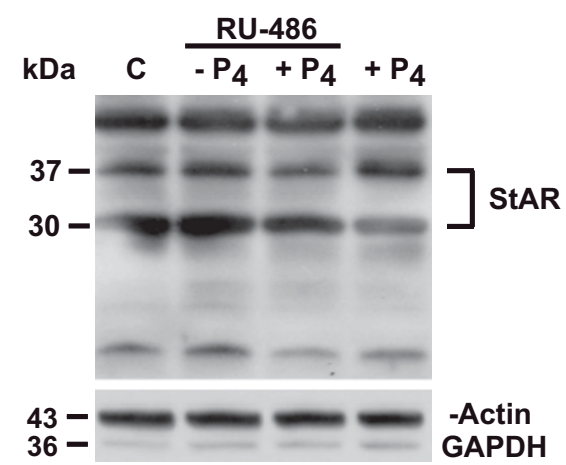

Figure $3 \mathbf{P}_{\mathbf{4}}$ signals via PR on hESCs. (a) hESCs treated $\pm P_{4}$ $(2 \mu M), R U-486(20 \mu M)$, and/or appropriate controls for 5 days were collected, and equal amounts of protein from cell lysates were analyzed by immunoblot for PR-A with anti-human PR rabbit polyclonal antibody (C-19) generated against the C-terminus, $\beta$-actin antibody and GAPDH antibody $[11,18]$. EBs were treated \pm RU-486 $(20 \mu M)$ and analyzed for these proteins. (b) hESCs were treated with and without $\mathrm{P}_{4}(2 \mu M)$ or RU-486 $(20 \mu M)$ or both for 5 days and analyzed with immunoblot for StAR, $\beta$-actin, and GAPDH. Molecular-weight markers are shown on the left of immunoblots.

and cholesterol uptake for the synthesis of sex steroids in $\mathrm{hESCs}$ and differentiating lineages.

Increasing concentrations of hCG suppress the pluripotent marker Oct-3/4 (Supplemental figure S2 in Additional file 1), suggesting that hCG, or steroid production initiated by hCG signaling, can direct lineage commitment. To test the effects of sex steroids on hESC proliferation and differentiation, we treated hESCs with $E_{2}, P_{4}$, and $E_{2}+P_{4}$ and observed a significant decrease in cell proliferation by $29 \%, 16 \%$, and $23 \%$, respectively, compared with untreated control (Figure 4a). These results were consistent with the slight decrease in cell proliferation observed after hCG treatment (Figure 1f) that induced significant $\mathrm{P}_{4}$ secretion (Figure $2 \mathrm{~b}$ ). A screen of germ-layer markers indicated that $\mathrm{P}_{4}$, and, to a lesser extent, $E_{2}$, increase the expression of nestin, an early marker of NPC formation, in hESCs (Figure $4 \mathrm{~b})$. Interestingly, $\mathrm{E}_{2}$ 'priming' has been shown to be required for induction of $\mathrm{PR}$ expression in other tissues [33]. Thus, the increase in nestin expression with $E_{2}$ treatment may reflect increased PR expression together with endogenous $\mathrm{P}_{4}$ signaling, and explain the current requirement for serum priming of hESC colonies in the preparation of neuroectodermal rosettes. Previous studies have demonstrated the importance of $\mathrm{P}_{4}$ and related steroids as neurotrophic agents that promote adult neurogenesis, neuronal survival, and neuroprotection [34-36].

The induction of nestin expression by $\mathrm{P}_{4}$ reveals a pivotal function for this pregnancy hormone during ectoderm formation. To confirm the requirement for $\mathrm{P}_{4}$ signaling in embryoblast development, hESC colonies just before entering the EB stage were treated with or without the PR antagonist RU-486 [37]. When compared with controls, colonies treated with RU-486 failed to form cystic structures (cavitation) and instead formed solid irregular spheres (Figure 4c) that did not express nestin (see Supplemental figure S3 in Additional file 1).

We next examined the requirement for $\mathrm{P}_{4}$ signaling during neurulation. hESC colonies grown into a pre-EB stage were treated with either $\mathrm{P}_{4}, \mathrm{RU}-486, \mathrm{P}_{4}+\mathrm{RU}-486$, or neither by using an especially made medium containing all ingredients except $\mathrm{P}_{4}$. In the presence of $\mathrm{P}_{4}$, control rosettes displayed a minimum of three rosette structures inside of the cavity (Figure 4c(iii)). Compared with controls, pre-EBs treated without $\mathrm{P}_{4}$ (Figure $4 \mathrm{c}(\mathrm{v})$ )or with RU-486 (Figure 4c(iv)) retained a spherical shape but failed to form rosettes with columnar neuroectodermal cells after 17 days in culture. Morphologic changes were more severe in the absence of $\mathrm{P}_{4}$ than with RU-486. That neuroectoderm failed to form was confirmed by the absence of nestin expression in RU-486-treated compared with $\mathrm{P}_{4}$-treated pre-EBs (Figure $4 \mathrm{~d}$ ). These results confirm our previously reported findings that $\mathrm{P}_{4}$ is the differentiation factor present in the neural induction media (N2 component) essential for neuroectodermal rosettes formation [4]. These results therefore suggest an obligatory role for $\mathrm{P}_{4}$ signaling in gastrulation and neurulation during early embryogenesis.

hCG/LH signaling via the LHCGR increases hESC proliferation, but also $\mathrm{P}_{4}$ synthesis that decreases cell 
(a)

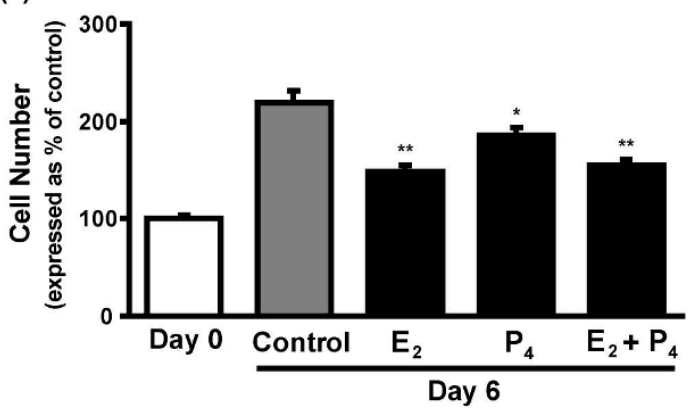

(c)
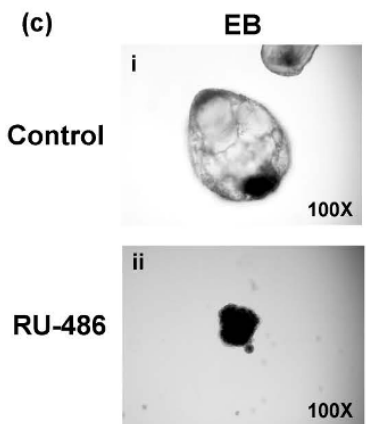

Rosettes
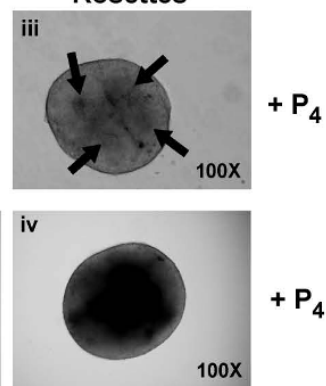

v

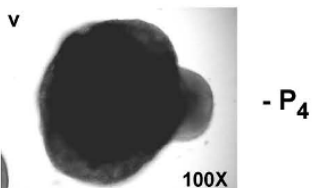

(b)

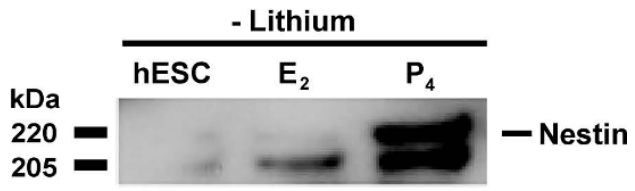

(d)

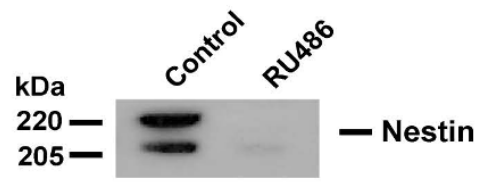

(e)

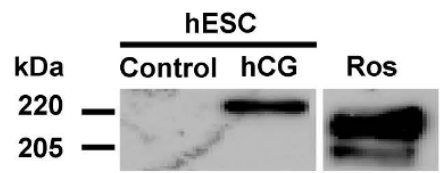

Figure $4 \mathrm{P}_{\mathbf{4}}$ promotes blastulation and neurulation. (a) hESCs were grown in lithium-free TESR1 medium in the presence of $E_{2}(10 \mathrm{nM})$ or $\mathrm{P}_{4}$ $(2 \mu M)$ or $E_{2}(10 \mathrm{nM})+P_{4}(2 \mu M)$ for 6 days, and cell numbers were measured by using the trypan blue assay. Results are expressed as mean \pm SEM, $n=4 ;{ }^{*} P<0.05$; ${ }^{*} P<0.005$ compared with 6 day control. (b) Equal amounts of protein from cell lysates of hESCs treated for 9 days as described earlier were analyzed with immunoblot by using a monoclonal antibody against nestin (clone 10C2). (c) EB formation: hESCs were allowed to form colonies by culturing for 4 days on an MEF feeder layer, as described earlier, and then were enzymatically lifted, and the colonies were placed into EB medium (containing serum) in the absence (i; control) or presence (ii) of RU-486 (20 $\mu M$ ) and rocked gently for an additional 10 days to allow EB formation. Structures were then assessed morphologically. Rosette formation: hESCs were allowed to form colonies by culturing for 4 days on an MEF feeder layer; colonies were then enzymatically lifted and placed into EB medium (containing serum) and rocked gently for an additional 4 days. Colonies were then placed in neural induction medium with $\mathrm{P}_{4}(2 \mu M)$ (iii), without $\mathrm{P}_{4}$ (v) or with $\mathrm{P}_{4}(2 \mu M)+\mathrm{RU}-486(20 \mu M)$ (iv) for an additional 11 days. At 19 days, the structures were analyzed morphologically. (d) The structures in (c) were collected, and equal amounts of protein from cell lysates were analyzed for nestin with immunoblot analysis. (e) hESCs were grown in mTeSR1 medium and treated with 500 mIU/ $\mathrm{ml} \mathrm{hCG}$ for 8 days. Cells were collected, protein content determined by using the BCA assay, equal amounts of protein were run on SDS-PAGE, and the immunoblot was probed for human nestin. Molecular-weight markers are shown on the left of immunoblots.

proliferation and promotes differentiation. At what point these functions bifurcate, and what other factors regulate hCG-induced proliferation versus hCG-induced $\mathrm{P}_{4}$ mediated differentiation (for example, BMP signaling) remain to be determined. Interestingly, hESCs default toward a primitive neural stem cell fate if maintained for any length of time in culture [38]. Because hESCs express gonadotropins (Figure 1b), and hCG signaling promotes $\mathrm{P}_{4}$ production (Figure $2 \mathrm{~b}$ ), which induces lineage commitment toward a neuroectodermal phenotype (Figures $4 \mathrm{~b}, \mathrm{c}$ ), we tested whether hCG might act to differentiate hESCs toward a neuronal lineage. hCG treatment induced nestin expression (205-kDa variant) in
hESCs (Figure 4e), indicating that endogenous gonadotropin production by hESCs (Figure 1) or trophoblastic cells [3] may be sufficient for NPC formation, thereby explaining the extrinsic hormonal signals regulating the 'default pathway' of hESC differentiation into neuronal lineages [38].

\section{Discussion}

These results indicate that trophoblastic hCG production adjacent to the embryoblast is required not only for trophoblast steroidogenesis and attachment to the uterine wall, but also for signaling normal growth and development of the embryoblast. hCG has known growth and 
differentiation functions during pregnancy, in which extravillous invasive cytotrophoblast cells $[39,40]$ or nonvillous cytotrophoblast cells $[41,42]$ secrete hyperglycosylated hCG that acts in an autocrine/paracrine manner to promote invasion [40,43]. Hyperglycosylated hCGinduced invasion of extravillous cytotrophoblast cells is critical for successful pregnancy implantation [44]. Hyperglycosylated hCG also promotes growth and invasion of choriocarcinoma cells across membranes in vitro and promotes extensive invasion, growth, and malignancy of choriocarcinoma cells transplanted into nude mice in vivo $[39,40]$. Regular hCG also has growth properties, promoting the induction of neoangiogenesis during endometrial vascularization $[45,46]$. Moreover, the free glycoprotein $\alpha$-subunit of gonadotropins has been shown to stimulate differentiation of prolactin cells in the pituitary [47] and endometrial stromal cell decidualization in the placenta [48]. As recently commented on, these well-described growth and malignancy properties of hCG have been largely neglected $[49,50]$. In our experiments, blocking LHCGR signaling with antisense and a specific blocking antibody suppressed hESC growth (Figure 2) strongly supports a role of hCG in promoting embryoblast growth. Although regular hCG did not increase cell proliferation above that of media containing no growth factors (Figure 1f), it is likely that either regular or glycosylated forms of hCG are the mitogenic factor promoting hESC division.

Although the structural importance of $\mathrm{P}_{4}$ and alloprogesterone has previously been recognized by its early synthesis (by at least day 13) within the developing rat central nervous system [51], our results demonstrate an earlier (within the first 7 days) and absolute requirement for $\mathrm{P}_{4}$ during both EB and neuroectodermal rosette differentiation, as indicated by the findings that (a) PR-A is expressed by hESCs and EBs, (b) RU-486 prevents normal cavitation of hESC colonies and columnar neuroectodermal rosette formation, (c) RU-486 prevents nestin expression, (d) $\mathrm{P}_{4}$ induces nestin expression in hESC, (e) $\mathrm{P}_{4}$ withdrawal from pre-EBs inhibits neuroectodermal rosette formation, and (f) hCG upregulates StAR processing for cholesterol transport and $\mathrm{P}_{4}$ synthesis and secretion. Extrapolation of these results from this model system would suggest that paracrine/juxtacrine signaling of hCG for mobilization of cholesterol for $\mathrm{P}_{4}$ production by the embryoblast/syncytiotrophoblast after conception is essential for blastulation and neurulation. The $\mathrm{P}_{4}$-induced differentiation of hESCs into neuroectodermal cells may be mediated by the alternate processing of the $\mathrm{A} \beta \mathrm{PP}$, because $\mathrm{A} \beta \mathrm{PP}$ processing toward the nonamyloidogenic pathway after the addition of $\mathrm{P}_{4}$ (neural induction media) is required for neural precursor cell formation [18].

Progestogens are demonstrated neurotrophic agents that promote adult neurogenesis, neuronal survival, and neuroprotection [34,35,52-58]. $\mathrm{P}_{4}$ is necessary and sufficient (in neurobasal media) for the maintenance and differentiation of primary hippocampal/cortical/striatal neurons in vitro [34]. That $\mathrm{P}_{4}$ is the hormone regulating these key early developmental events is consistent with its location high in the steroid synthetic pathway; $\mathrm{P}_{4}$ is the first steroid synthesized from pregnenolone, the precursor to all other steroids. Moreover, the expression of PR-A by $\mathrm{hESCs}$ and EBs, and the findings that PR-A expression is not altered by either agonists or antagonists suggests an important function for PR-A signaling early in embryogenesis. The potential for $\mathrm{P}_{4}$ to regulate organogenesis has been reported during puberty and adulthood, in which $\mathrm{P}_{4}$ is obligatory for the development of the tertiary ducts on the mammary gland, and the physiological differentiation of the lobuloalveolar system from the lobular buds [59]. In the adult, $\mathrm{P}_{4}$ also has been demonstrated to regulate bone formation [60], promote angiogenesis and arteriogenesis [61], and promote formation of the placenta.

Support for LH in mediating neurogenesis has been reported in mice, in which LH induces neurogenesis in the adult hippocampus [62]. Whether these properties of $\mathrm{LH} / \mathrm{hCG}$ in the adult brain are mediated via $\mathrm{P}_{4}$, as we demonstrated for hESCs (Figures 1 through 4) remains to be determined, although progestogens have been shown to increase significantly rat neuroprogenitor cell and human neural stem cell proliferation $[35,63]$, and to promote neurite development and migration that lead to changes in synaptogenesis [64-67]. The autocrine/paracrine signaling of hCG for $\mathrm{P}_{4}$ synthesis within the blastocyst is consistent with the recent findings that a 'miniHPG' axis appears within the extrahypothalamic/pituitary brain that serves to regulate brain neurosteroid production [68]. Identification of other members (hormones and hormone receptors) of the HPG axis that regulate hCG/LH production, for example, might be predicted.

The requirement for $\mathrm{P}_{4}$ during cavitation processes indicates the structural influence of these molecular pathways on the developing embryo within the first 7 days, but also on the formation of the neural tube at around day 17 to 19 , which will influence future neural connectivity. The suppression of $\mathrm{P}_{4}$ signaling at this time (for example, with RU-486) [69] will block these time-sensitive developmental processes. Given that the relative binding affinity of RU-486 for the PR is twice that of $\mathrm{P}_{4}$ [70], and that treatment of hESC with $20 \mu M$ RU-486 in our study (Figures 3 and 4 ) is equivalent to the dosage used for the termination of pregnancies $(\sim 6-$ $19 \mu M$ ) [37], administration of RU-486 would clearly have a negative effect on the developing embryo. Thus, the abortifacient effects of RU-486 in blocking PR signaling therefore also extend to blocking blastulation and neurulation and the normal growth and development of the embryo. 


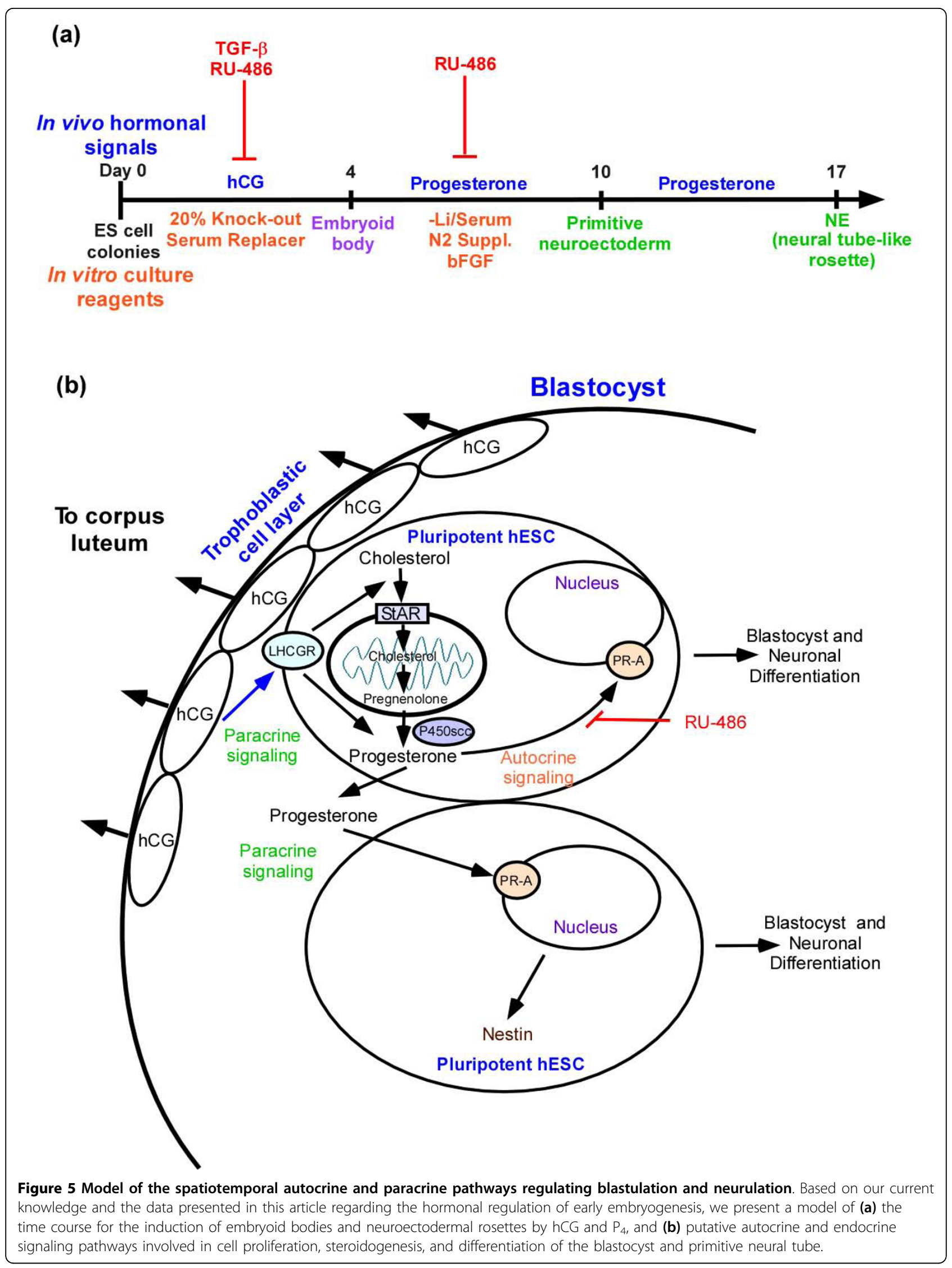


The maintenance of hESCs in a pluripotent state in culture is dependent on the presence of a member of the FGF family as well as a member of the TGF- $\beta$ superfamily [25]. Whether FGF and TGF- $\beta$ also are physiologic signals produced by trophoblastic cells that signal the embryoblast is unknown, although FGF and activins have known growth and differentiation properties $[13,71]$.

We present a model of the time course for in vitro differentiation of hESCs into an EB and into a neuroectodermal rosette with the physiological hormones hCG and $\mathrm{P}_{4}$ (Figure $5 \mathrm{a}$ ), and of the autocrine and paracrine pathways within the blastocyst that might operate to regulate blastocyst and neuroectodermal development (Figure 5b). Our data suggest that trophoblastic hCG production adjacent to the embryoblast could be required, not only for trophoblast steroidogenesis and attachment of the blastocyst to the uterine wall [72], but also for signaling normal proliferation and differentiation of the embryoblast. hCG-induced $\mathrm{P}_{4}$ synthesis therefore has, in addition to its role in uterine decidualization for the implantation and maintenance of pregnancy, an obligatory role before the formation of neural precursor cells (blastulation), as well as an inductive role in the directed differentiation and specification of the first neuronal cell types (organogenesis; Figure 4) and the formation of the neural tube. If future in vivo studies should confirm these in vitro results, this paracrine/ juxtacrine signaling by extraembryonic tissues would be the commencement of trophic support by placental tissues in the growth and development of the human embryo.

\section{Conclusions}

This work demonstrates that hCG signaling via the LHCGR induces hESC proliferation. Differentiation of hESCs into neural precursor cells was mediated by the upregulation of steroidogenesis by hCG signaling through the LHCGR. Suppression of progesterone $\left(\mathrm{P}_{4}\right)$ signaling inhibited EB and neuroectodermal rosette formation, suggesting an obligatory role for this steroidogenic pathway during hESC differentiation. Together our results suggest that pregnancy-associated hCG and $\mathrm{P}_{4}$ could be physiologic signals that promote proliferation and differentiation during blastulation and neurulation.

\section{Additional material}

Additional file 1: Additional data. LHCGR mRNA expression in hESCs (Supplemental figure S1); LH and hCG regulation of Oct-3/4 expression in hESC (Supplemental figure S2); progesterone regulation of nestin expression in EBs and rosettes (Supplemental figure S3).

\section{Abbreviations}

$E_{2}$ : 17ק-estradiol; EBs: embryoid bodies; EIA: enzyme immunoassay; hCG: human chorionic gonadotropin; hESCs: human embryonic stem cells; LHCGR: luteinizing hormone/chorionic gonadotropin receptor; NPCs: neural precursor cells; $P_{4}$ : progesterone; $P R-A$ : $P_{4}$ receptor-A; StAR: steroid acute regulatory protein.

\section{Acknowledgements}

We thank the WiCell Research Institute (Madison, WI) for providing hESCs and technical expertise. This research was supported in part by the Office of Research and Development, Department of Veteran Affairs, and the Alzheimer's Association. This is Geriatrics Research, Education and Clinical Center VA paper number 2010-15.

\section{Author details}

${ }^{1}$ Geriatric Research, Education and Clinical Center, Veterans Administration Hospital and Department of Medicine, University of Wisconsin-Madison School of Medicine and Public Health, 2500 Highland Avenue, Madison, WI 53705, USA. ²Duke University, Department of Medicine, Chapel Drive, Durham, NC 27708, USA. ${ }^{3}$ Institute of Pathology, Case Western Reserve University, 2103 Cornell Road, Cleveland, $\mathrm{OH} 44106$, USA. ${ }^{4}$ School of Exercise, Biomedical and Health Sciences, Edith Cowan University, 270 Joondalup Drive, Joondalup, 6027 WA, Australia. ${ }^{5}$ Department of Neurological Surgery, University of Wisconsin-Madison School of Medicine and Public Health, 600 Highland Avenue, Madison, WI 53792, USA.

\section{Authors' contributions}

MJG maintained the hESCs, designed and performed the experiments, analyzed the data, interpreted the results and helped write the manuscript. PP maintained the hESCs, performed the experiments, and analyzed the data. MMK maintained the hESCS. RLB helped conceive the hCG experiments. SVM performed the experiments on PR, interpreted results, and helped write the manuscript. CSA conceived the study, participated in its design and coordination, interpreted the data, and wrote the manuscript.

\section{Competing interests}

The authors declare that they have no competing interests.

Received: 18 June 2010 Accepted: 13 September 2010

Published: 13 September 2010

\section{References}

1. Zhuang $L Z, L i R H$ : Study on reproductive endocrinology of human placenta (II): hormone secreting activity of cytotrophoblast cells. Sci China B 1991, 34:1092-1097.

2. Pidoux G, Gerbaud P, Tsatsaris V, Marpeau O, Ferreira F, Meduri G, Guibourdenche J, Badet J, Evain-Brion D, Frendo JL: Biochemical characterization and modulation of LH/CG-receptor during human trophoblast differentiation. J Cell Physiol 2007, 212:26-35.

3. Gerami-Naini B, Dovzhenko OV, Durning M, Wegner FH, Thomson JA, Golos TG: Trophoblast differentiation in embryoid bodies derived from human embryonic stem cells. Endocrinology 2004, 145:1517-1524.

4. Gallego MJ, Porayette P, Kaltcheva MM, Meethal SV, Atwood CS: Opioid and progesterone signaling is obligatory for early human embryogenesis. Stem Cells Dev 2009, 18:737-740.

5. Braunstein GD, Rasor J, Danzer H: Serum human chorionic gonadotropin levels throughout normal pregnancy. Am J Obstet Gynecol 1976, 126:678.

6. Carr BR, MacDonald PC, Simpson ER: The role of lipoproteins in the regulation of progesterone secretion by the human corpus luteum. Fertil Steril 1982, 38:303-311.

7. Pepe GJ, Albrecht ED: Actions of placental and fetal adrenal steroid hormones in primate pregnancy. Endocr Rev 1995, 16:608-648.

8. Fiddes JC, Talmadge K: Structure, expression, and evolution of the genes for the human glycoprotein hormones. Recent Prog Horm Res 1984, 40:43-78.

9. Vadakkadath Meethal S, Atwood CS: The role of hypothalamic-pituitarygonadal hormones in the normal structure and functioning of the brain. Cell Mol Life Sci 2005, 62:257-270. 
10. Bowen RL, Atwood CS: Living and dying for sex: a theory of aging based on the modulation of cell cycle signaling by reproductive hormones. Gerontology 2004, 50:265-290.

11. Porayette P, Gallego MJ, Kaltcheva MM, Meethal SV, Atwood CS: Amyloidbeta precursor protein expression and modulation in human embryonic stem cells: a novel role for human chorionic gonadotropin. Biochem Biophys Res Commun 2007, 364:522-527.

12. Cole LA: New discoveries on the biology and detection of human chorionic gonadotropin. Reprod Biol Endocrinol 2009, 7:8.

13. Ludwig TE, Bergendahl V, Levenstein ME, Yu J, Probasco MD, Thomson JA: Feeder-independent culture of human embryonic stem cells. Nat Methods 2006, 3:637-646.

14. Itskovitz-Eldor J, Schuldiner M, Karsenti D, Eden A, Yanuka O, Amit M, Soreq $\mathrm{H}$, Benvenisty N: Differentiation of human embryonic stem cells into embryoid bodies compromising the three embryonic germ layers. Mol Med 2000, 6:88-95.

15. Li X, Zhang S: In vitro differentiation of neural precursors from human embryonic stem cells. Methods Mol Biol 2006, 331:169-177.

16. Muller $F$, O'Rahilly R: The first appearance of the neural tube and optic primordium in the human embryo at stage 10. Anat Embryol (Berl) 1985, 172:157-169.

17. Zhang SC: Embryonic stem cells for neural replacement therapy: prospects and challenges. J Hematother Stem Cell Res 2003, 12:625-634.

18. Porayette P, Gallego MJ, Kaltcheva MM, Bowen RL, Vadakkadath Meethal S, Atwood CS: Differential processing of amyloid-beta precursor protein directs human embryonic stem cell proliferation and differentiation into neuronal precursor cells. J Biol Chem 2009, 284:23806-23817.

19. Liu T, Perry G, Chan HW, Verdile G, Martins RN, Smith MA, Atwood CS: Amyloid-beta-induced toxicity of primary neurons is dependent upon differentiation-associated increases in tau and cyclin-dependent kinase 5 expression. J Neurochem 2004, 88:554-563.

20. Wilson AC, Salamat MS, Haasl RJ, Roche KM, Karande A, Meethal SV, Terasawa E, Bowen RL, Atwood CS: Human neurons express type I GnRH receptor and respond to GnRH I by increasing luteinizing hormone expression. J Endocrinol 2006, 191:651-663.

21. Sugawara T, Kiriakidou M, McAllister JM, Holt JA, Arakane F, Strauss JF: Regulation of expression of the steroidogenic acute regulatory protein (StAR) gene: a central role for steroidogenic factor 1. Steroids 1997, 62:5-9.

22. O'Shea KS: Embryonic stem cell models of development. Anat Rec 1999, 257:32-41.

23. Strewler G: Humoral manifestations of malignancy. In Williams Textbook of Endocrinology. Edited by: Larsen P, Kronenberg H, Melmed S, Polonsky K. Philadelphia: Saunders; , 10 2002:1834-1856.

24. Bowen RL, Verdile G, Liu T, Parlow AF, Perry G, Smith MA, Martins RN, Atwood CS: Luteinizing hormone, a reproductive regulator that modulates the processing of amyloid-beta precursor protein and amyloid-beta deposition. J Biol Chem 2004, 279:20539-20545.

25. Thomson JA, Itskovitz-Eldor J, Shapiro SS, Waknitz MA, Swiergiel JJ, Marshall VS, Jones JM: Embryonic stem cell lines derived from human blastocysts. Science 1998, 282:1145-1147.

26. Molsberry RL, Carr BR, Mendelson CR, Simpson ER: Human chorionic gonadotropin binding to human fetal testes as a function of gestational age. J Clin Endocrinol Metab 1982, 55:791-794.

27. Channing CP, Kammerman S: Binding of gonadotropins to ovarian cells. Biol Reprod 1974, 10:179-198.

28. Matin MM, Walsh JR, Gokhale PJ, Draper JS, Bahrami AR, Morton I, Moore HD, Andrews PW: Specific knockdown of Oct4 and beta2microglobulin expression by RNA interference in human embryonic stem cells and embryonic carcinoma cells. Stem Cells 2004, 22:659-668.

29. Strauss JF, Christenson LK, Devoto L, Martinez F: Providing progesterone for pregnancy: control of cholesterol flux to the side-chain cleavage system. J Reprod Fertil Suppl 2000, 55:3-12.

30. Stocco DM: StAR protein and the regulation of steroid hormone biosynthesis. Annu Rev Physiol 2001, 63:193-213.

31. Hong SH, Nah HY, Lee YJ, Lee JW, Park JH, Kim SJ, Lee JB, Yoon HS, Kim CH: Expression of estrogen receptor-alpha and - beta, glucocorticoid receptor, and progesterone receptor genes in human embryonic stem cells and embryoid bodies. Mol Cells 2004, 18:320-325.
32. Sauter CN, McDermid RL, Weinberg AL, Greco TL, Xu X, Murdoch FE, Fritsch MK: Differentiation of murine embryonic stem cells induces progesterone receptor gene expression. Exp Cell Res 2005, 311:251-264.

33. Mylonas I, Jeschke U, Shabani N, Kuhn C, Kunze S, Dian D, Friedl C, Kupka MS, Friese K: Steroid receptors ERalpha, ERbeta, PR-A and PR-B are differentially expressed in normal and atrophic human endometrium. Histol Histopathol 2007, 22:169-176.

34. Brewer GJ, Torricelli JR, Evege EK, Price PJ: Optimized survival of hippocampal neurons in B27-supplemented Neurobasal, a new serumfree medium combination. J Neurosci Res 1993, 35:567-576.

35. Wang JM, Johnston PB, Ball BG, Brinton RD: The neurosteroid allopregnanolone promotes proliferation of rodent and human neural progenitor cells and regulates cell-cycle gene and protein expression. $J$ Neurosci 2005, 25:4706-4718.

36. Stein DG, Wright DW, Kellermann AL: Does progesterone have neuroprotective properties? Ann Emerg Med 2008, 51:164-172.

37. Mifegyne UK: Summary of Product Characteristics (SPC). [http://emc. medicines.org.uk/emc/assets/c/html/displaydoc.asp?documentid=617]

38. Munoz-Sanjuan I, Brivanlou AH: Neural induction, the default model and embryonic stem cells. Nat Rev Neurosci 2002, 3:271-280.

39. Cole LA, Khanlian SA, Riley JM, Butler SA: Hyperglycosylated hCG in gestational implantation and in choriocarcinoma and testicular germ cell malignancy tumorigenesis. J Reprod Med 2006, 51:919-929.

40. Cole LA, Dai D, Butler SA, Leslie KK, Kohorn El: Gestational trophoblastic diseases, 1: pathophysiology of hyperglycosylated hCG. Gynecol Oncol 2006, 102:145-150

41. Hamada AL, Nakabayashi K, Sato A, Kiyoshi K, Takamatsu Y, LaoagFernandez JB, Ohara N, Maruo T: Transfection of antisense chorionic gonadotropin beta gene into choriocarcinoma cells suppresses the cell proliferation and induces apoptosis. J Clin Endocrinol Metab 2005, 90:4873-4879.

42. Lei Z, Taylor D, Gercel-Taylor C, Rao C: Human chorionic gonadotropin promotes tumorigenesis of choriocarcinoma JAR cells. Trophoblast Res 1999, 13:147-159.

43. Handschuh K, Guibourdenche J, Tsatsaris V, Guesnon M, Laurendeau I, Evain-Brion D, Fournier T: Human chorionic gonadotropin produced by the invasive trophoblast but not the villous trophoblast promotes cell invasion and is down-regulated by peroxisome proliferator-activated receptor-gamma. Endocrinology 2007, 148:5011-5019.

44. Sasaki Y, Ladner DG, Cole LA: Hyperglycosylated human chorionic gonadotropin and the source of pregnancy failures. Fertil Steril 2008, 89:1781-1786.

45. Shi QJ, Lei ZM, Rao CV, Lin J: Novel role of human chorionic gonadotropin in differentiation of human cytotrophoblasts. Endocrinology 1993, 132:1387-1395.

46. Licht P, Russu V, Wildt L: On the role of human chorionic gonadotropin (hCG) in the embryo-endometrial microenvironment: implications for differentiation and implantation. Semin Reprod Med 2001, 19:37-47.

47. Avsian-Kretchmer O, Hsueh AJ: Comparative genomic analysis of the eight-membered ring cystine knot-containing bone morphogenetic protein antagonists. Mol Endocrinol 2004, 18:1-12.

48. Blithe DL, Richards RG, Skarulis MC: Free alpha molecules from pregnancy stimulate secretion of prolactin from human decidual cells: a novel function for free alpha in pregnancy. Endocrinology 1991, 129:2257-2259.

49. Trudeau VL: Really old hormones up to new tricks: glycoprotein hormone subunits may have roles in development. Endocrinology 2009, 150:3446-3447.

50. Dos Santos S, Bardet C, Bertrand S, Escriva H, Habert D, Querat B: Distinct expression patterns of glycoprotein hormone-alpha2 and -beta5 in a basal chordate suggest independent developmental functions. Endocrinology 2009, 150:3815-3822.

51. Pomata PE, Colman-Lerner AA, Baranao JL, Fiszman ML: In vivo evidences of early neurosteroid synthesis in the developing rat central nervous system and placenta. Brain Res Dev Brain Res 2000, 120:83-86.

52. Schumacher M, Guennoun R, Robert F, Carelli C, Gago N, Ghoumari A, Gonzalez Deniselle MC, Gonzalez SL, Ibanez C, Labombarda F, Coirini H, Baulieu EE, De Nicola AF: Local synthesis and dual actions of progesterone in the nervous system: neuroprotection and myelination. Growth Horm IGF Res 2004, 14 Suppl A:S18-S33. 
53. Schumacher A, Arnhold S, Addicks K, Doerfler W: Staurosporine is a potent activator of neuronal, glial, and "CNS stem cell-like" neurosphere differentiation in murine embryonic stem cells. Mol Cell Neurosci 2003, 23:669-680.

54. Mauch DH, Nagler K, Schumacher S, Goritz C, Muller EC, Otto A, Pfrieger FW: CNS synaptogenesis promoted by glia-derived cholesterol. Science 2001, 294:1354-1357.

55. Ciriza I, Carrero P, Azcoitia I, Lundeen SG, Garcia-Segura LM: Selective estrogen receptor modulators protect hippocampal neurons from kainic acid excitotoxicity: differences with the effect of estradiol. J Neurobiol 2004, 61:209-221.

56. VanLandingham JW, Cutler SM, Virmani S, Hoffman SW, Covey DF, Krishnan K, Hammes SR, Jamnongjit M, Stein DG: The enantiomer of progesterone acts as a molecular neuroprotectant after traumatic brain injury. Neuropharmacology 2006, 51:1078-1085.

57. Cutler SM, VanLandingham JW, Murphy AZ, Stein DG: Slow-release and injected progesterone treatments enhance acute recovery after traumatic brain injury. Pharmacol Biochem Behav 2006, 84:420-428.

58. Guo Q, Sayeed I, Baronne LM, Hoffman SW, Guennoun R, Stein DG: Progesterone administration modulates AQP4 expression and edema after traumatic brain injury in male rats. Exp Neurol 2006, 198:469-478.

59. Atwood CS, Hovey RC, Glover JP, Chepko G, Ginsburg E, Robison WG Vonderhaar BK: Progesterone induces side-branching of the ductal epithelium in the mammary glands of peripubertal mice. J Endocrinol 2000, 167:39-52.

60. Prior JC: Progesterone as a bone-trophic hormone. Endocr Rev 1990, 11:386-398.

61. Rogers PA, Donoghue JF, Walter LM, Girling JE: Endometrial angiogenesis, vascular maturation, and lymphangiogenesis. Reprod Sci 2009, 16:147-151.

62. Mak GK, Enwere EK, Gregg C, Pakarainen T, Poutanen M, Huhtaniemi I, Weiss S: Male pheromone-stimulated neurogenesis in the adult female brain: possible role in mating behavior. Nat Neurosci 2007, 10:1003-1011.

63. Gould $E$, Tanapat $P$, Rydel $T$, Hastings N: Regulation of hippocampal neurogenesis in adulthood. Biol Psychiatry 2000, 48:715-720.

64. McEwan PE, Lindop GB, Kenyon CJ: Control of cell proliferation in the rat adrenal gland in vivo by the renin-angiotensin system. Am J Physiol 1996, 271:E192-198.

65. Masumoto A, Natori S, Iwamoto H, Uchida E, Ohashi M, Sakamoto S, Nawata H: Effect of insulin, glucagon or dexamethasone on the production of insulin-like growth factor I in cultured rat hepatocytes. Fukuoka lgaku Zasshi 1991, 82:136-141.

66. Leranth C, Shanabrough M, Redmond DE Jr: Gonadal hormones are responsible for maintaining the integrity of spine synapses in the CA1 hippocampal subfield of female nonhuman primates. $J$ Comp Neurol 2002, 447:34-42

67. Simerly RB: Wired for reproduction: organization and development of sexually dimorphic circuits in the mammalian forebrain. Annu Rev Neurosci 2002, 25:507-536.

68. Meethal SV, Liu T, Chan HW, Ginsburg E, Wilson AC, Gray DN, Bowen RL, Vonderhaar BK, Atwood CS: Identification of a regulatory loop for the synthesis of neurosteroids: a steroidogenic acute regulatory proteindependent mechanism involving hypothalamic-pituitary-gonadal axis receptors. J Neurochem 2009, 110:1014-1027.

69. Fiala C, Gemzel-Danielsson K: Review of medical abortion using mifepristone in combination with a prostaglandin analogue. Contraception 2006, 74:66-86.

70. Heikinheimo O, Kekkonen R, Lahteenmaki P: The pharmacokinetics of mifepristone in humans reveal insights into differential mechanisms of antiprogestin action. Contraception 2003, 68:421-426.

71. Ludwig TE, Levenstein ME, Jones JM, Berggren WT, Mitchen ER, Frane JL, Crandall LI, Daigh CA, Conard KR, Piekarczyk MS, Llanas RA, Thomson JA: Derivation of human embryonic stem cells in defined conditions. Nat Biotechnol 2006, 24:185-187.

72. Wahabi H, Abed Althagafi N, Elawad M: Progestogen for treating threatened miscarriage. Cochrane Database Syst Rev 2007, CD005943.

doi:10.1186/scrt28

Cite this article as: Gallego et al:: The pregnancy hormones human chorionic gonadotropin and progesterone induce human embryonic stem cell proliferation and differentiation into neuroectodermal rosettes. Stem Cell Research \& Therapy 2010 1:28.

\section{Submit your next manuscript to BioMed Central and take full advantage of:}

- Convenient online submission

- Thorough peer review

- No space constraints or color figure charges

- Immediate publication on acceptance

- Inclusion in PubMed, CAS, Scopus and Google Scholar

- Research which is freely available for redistribution 